\title{
Self-Regulation Capacity and Decision Making of Slovak Managers in Routine Situations and in Situations with Possible Negative Outcomes
}

\author{
Peter Halama \\ Institute of Experimental Psychology \\ Center of Social and Psychological Sciences, Slovak Academy of Sciences
}

\begin{abstract}
The study focuses on the relationship between self-regulation and decision making of Slovak managers in work-related situations involving routine circumstances and circumstances where inappropriate decision may lead to possible serious negative consequences. 143 Slovak managers were asked to choose some work-related situation of decision making and to assess it on the scales provided (routine or not routine, with or without possible negative consequences). They were administered a Self-Regulation Scale (Schwarzer et al., 1999) and Melbourne Decision Making Questionnaire (MDMQ) (Mann et al., 1997), adapted for the assessment of current decision making behavior. The results showed that self-regulation correlated positively with vigilant decision making and negatively with maladaptive decision making, such as buck-passing, hypervigilance, and procrastination. Moderation analysis revealed that situations with possible negative consequences weaken the relationship between self-regulation and both vigilance as well as maladaptive decision making.
\end{abstract}

Key words: self-regulation, decision making, managers, situational approach

\section{Introduction}

In the beginning, research of decision making was frequently focused on the consideration of possible options or alternatives and on searching for information and ways of reframing the situation of decision making to achieve a proper decision (see Edwards, 1954; Kahneman \& Twersky, 1984). These approaches lead to many significant findings related to choice and information processing, however, they failed to describe the differences in successful attain-

This work was supported by the Slovak Research and Development Agency under the contract No. APVV-0361-12.

Correspondence concerning this article should be addressed to Peter Halama, Institute of Experimental Psychology, Center of Social and Psychological Sciences, Slovak Academy of Sciences, Dúbravská cesta 9, 84104 Bratislava, Slovak Republic. E-mail: peter.halama@savba.sk

Received January 21, 2017 ment of the chosen options (Byrnes, 1998). These differences are usually related to specific individual dispositions, which have an effect on optimal decision making and the process of attaining chosen goals. Several individual dispositions were found to be positive factors in optimal decision making, such as the capacity of cognitive reflection (Frederick, 2005), emotional stability (Miu et al., 2008), etc. One of the most discussed individual dispositions related to decision making is self-regulation capacity, which became a part of several models or approaches to decision making (Byrnes, 1998; Higgins, 2002; Vohs et al., 2008).

In general, self-regulation is understood as an effort to reach personal goals and control unwanted impulses, usually of emotional nature (Halama, 2014). More specific definition by Vohs et al. (2008) states that self-regulation is a self-exerting control to override a prepotent response, with the assumption that replacing one response with another is done to attain goals and conform to standards. Several models and 
concepts of self-regulation have been described in scientific literature. Carver and Scheier (1981, 1998, 2012) understand self-regulation as a process based on the feedback loops. A person in this model moves toward a specific goal and receives information about possible discrepancy between his or her activity and the approaching goal. This information serves as a source for adaption of the consequent behavior in order to increase probability of goal attainment. Mischel (1996; Metcalfe \& Mischel, 1999) proposed that self-regulatory capacity depends on the ability to switch between hot and cool system (cognitive/reflective vs. emotional/reactive) and maintain balance between them. Special role in this dynamics is played by cognitive abilities, which can help reframe hot stimuli and keep the attention on pursuing the chosen goal. Baumaister (2002, Baumaister et al., 1998) suggested that self-regulation draws on the limited sources. In his ego depletion theory, self-regulation failure happens because sources used by an individual are depleted by previous self-regulation.

Several studies have focused on the relationship between self-regulation and decision making. Golwitzer and Sheeran (2009) proposed the existence of so called implementation intentions, which are sources for self-regulatory efforts. In consumer behavior, proper intentions can regulate decision making and contribute to constructive ways of decision making, e.g. attention control, information elaboration, and overcoming disruptive influences. Vohs et al. (2008) used the ego-depletion approach in their study and found that self-regulation and decision making are mutually related. In their research, they focused on choices, which are understood more broadly than decision making, because decision making includes only the situations in which conscious reflective choice is involved (Arrow, 1958). They pointed out that making choices can negatively affect later self-regulation, since the effort to make choices comes from the same source as self-regulation and can consume energy. This can lead not only to selfregulation failure but also to improper decisions due to the lack of energy for the elaborated conscious reflective process of decision making. Higgins (2002; Crowe \& Higgins, 1999) suggested that the link between self-regulation and decision making is a regulatory focus. Regulatory focus is two-fold: promotion focus is oriented towards attainment of positive outcomes and prevention focus towards avoidance of negative outcomes. Preference of one or the other focus influences decision making especially through preference of information, i.e. people with prevention focus can be more sensitive to information related to avoiding something negative. Byrnes (1998; 2005; Byrnes et al., 1998) emphasizes that the capacity of effective decision increases with age. This fact is related to endogenous tendency towards selfregulation, which provides for beliefs correction and searching for feedback. In this concept, it is self-regulation maturity that is responsible for proper decisions.

The significance of self-regulation in the decision making process seems to be especially important in professional settings. Similar to persons in everyday life, professionals from different areas have to deal with complex and difficult tasks, which in many cases are accompanied by emotional feelings. However, in case of professionals, failure of self-regulation related to negative emotions can have strong economic and societal consequences, depending on the amount of responsibility associated with the specific job position (e.g., bankruptcy in case of managers).

Mosier and Fischer (2010) distinguish emotions which are relevant or irrelevant to the task. Relevant emotions are those, which provide important information and guiding for solving the task. On the other hand, irrelevant emotions come from other sources such as mood, emotional experiences outside the problem, etc. Es- 
pecially irrelevant emotions, such as anxiety, can have negative impact on decision making because they reduce cognitive capacity and lead to preference of stimuli related to threat (e.g., Eysenck et al., 2007; Derakshan \& Eysenck, 2009). Halama and Gurňáková (2013) described an example of a paramedic team, who seriously failed to correctly interpret information about a patient because they were negatively influenced by anxiety born from their previous intervention. This suggests that capacity of self-regulation is one of the most important factors in professional decision making and can eliminate the negative impact of anxiety on work achievement, including decision making (Baumann et al., 2001). Recent research has confirmed this fact. Jurišová and Sarmány-Schuller (2013) found that in a sample of paramedic students, self-regulation was positively related to vigilant decision-making style and negatively to hypervigilance and procrastination. Similar results were confirmed in a sample of nurses as well (Halama \& Pitel, 2016). In addition, this study showed that self-regulation acted as a mediator in the relationship between attachment and decision making.

In this study, an interactional approach is applied to the problem of decision making. This approach assumes that behavior is a result of mutual interaction between personality and situational characteristics (Endler \& Edwards, 1986). Previous research has confirmed that interactional approach can be useful a framework for the study of work achievement in different areas (Hochwarter et al., 2006; Tett \& Burnet, 2003). My previous studies also showed that interactional approach can provide deeper insight in the area of decision making, since it takes into account stable personality characteristics as well as specific situational attributes (Halama, 2013; Halama, 2016). Both these factors have not only an independent effect on decision making but together they form specific effects.
Concerning specific characteristics of work situations related to decision making, previous studies suggested that it is important to distinguish between routine and non-routine situations (e.g., Betsch et al., 2002; Richters et al., 2016; Sedlár, 2016). While routine situations are usually characterized by high level of certainty, self-confidence and application of decision making procedures, which rely on a particular option activated by a situation, non-routine situation involves high level of uncertainty, disruption of standard procedures and application of decision making strategies based on the reframing of an unfamiliar situation (Richters et al., 2016). In many non-routine situations, especially in a work setting, wrong decisions can have negative consequences (Richters et al., 2016). Such consequences can lead to experience of negative emotions such as anxiety, worry, etc., and can influence the cognitive processes underlying decision making (Baumann et al., 2001). As self-regulation can play an important role in such situations, it is important to provide deeper insight in the process of how these situation characteristics (routine vs. negative consequences) interact with self-regulation and decision making processes. This study focuses on self-regulation and its role in decision making in specific work-related situations on the part of Slovak managers. The main research questions are how self-regulation is related to the specific decision making variables in Slovak managers and how this relationship is moderated by situational characteristics. These questions come from the empirically verified fact that self-regulation capacity is in a substantial relationship with the decision making process and this is also valid for work-related situations of decision making in managerial settings. The first goal of the study is to identify a possible relationship between self-regulation capacity and the ways of decision making in specific work-related situations. Moreover, there is an assumption of a situational effect. This means 
that the relationship between self-regulation and decision making differs according to the situation characteristics and this study aims to identify possible occurrence of this effect. As suggested above, I studied two specific kinds of situations as moderators: situations with possible serious negative outcomes arising from the decision and situations of routine decision making.

\section{Method}

\section{Sample}

Research sample consisted of 143 Slovak managers from both private and public areas. The managers were recruited through an online panel of a research agency. 77 of them were males and 66 females. The mean age of the participants was 41.7 years with standard deviation of 12.68 years. The time in current work position ranged from 1 to 35 years, with a mean of 9.36 and standard deviation of 7.88 years. The work domains of the managers included several areas but most frequently finance (16), business and marketing (14), personal management (13), education (13), and building industry (11). Other domains were IT technology (9), transport and logistics (9), unspecified industry (10), etc. The criterion for inclusion was a positive answer to the question of managing projects or other people in their work.

Managers were asked to choose one specific work-related situation in which they had to make a decision. Subsequently, they were asked to assess this situation, their behavior in this situation as well as themselves in general. The specific situations described by the managers included a wide range of different events. The most frequent situations were personnel matters, such as hiring, replacing or selecting employees (e.g., selecting suitable people for specific projects), situations related to technology process (e.g., selecting most effective and economical technology related to a new contract), and situations with specific work-related circumstances requiring the need to find a solution or make the appropriate decision (e.g., malfunction of devices requiring a decision to interrupt the production process or not).

\section{Measures}

For measuring self-regulation, the Self-Regulation Scale (SRS) (Schwarzer et al., 1999; Diehl et al., 2006) was used. It is a self-report questionnaire, developed to cover emotional and attention aspects of self-regulation. It assesses a person's ability to maintain his or her focus of attention when pursuing a goal and facing difficulties in achieving the goal. The scale contains 10 items, which are rated on a 4-point scale ranging from 1 (not at all true) to 4 (completely true). Responses are summed into a total score, with higher scores indicating greater ability to control and maintain one's attention. The psychometric analysis of Diehl et al. (2006) revealed that the scale showed good internal constituency and also satisfactory test-retest reliability over a 6 -week period. The criterion validity of the scale was supported by positive correlations with contentrelated measures. Concerning this sample, the internal consistency estimated by Cronbach alpha coefficient was 0.86 .

To measure the ways of decision making in specific situations, I used a specifically adjusted form of the Melbourne Decision Making Questionnaire (MDMQ) (Mann et al., 1997). Originally, this scale is a measure of decision making styles, but in this study the instruction was adapted from typical behavior in decision situations into specific behavior in the situation described by the manager him- or herself. The scale contains 22 items which are answered on a 3-point scale from True for me to Not true for $m e$. The measure detects four decision making 
ways as described above: Vigilance (VGL) includes clarifying of the objectives to be achieved by the decision, canvassing alternatives, searching for relevant information, and assimilating it in an unbiased manner, and evaluating alternatives carefully before making a choice. Hypervigilance (HVG) means that the decision maker searches frantically for a way out of dilemmas. Due to time pressure, the decision maker impulsively seizes upon hastily contrived solutions that seem to promise immediate relief. Buck-passing (BP) includes attribution of responsibility for one's own decisions to another person or group with responsibility. It is also associated with hesitation in decision making. Finally, Procrastination (PRO) means replacing high-priority actions with tasks of lower priority, or doing something from which one derives enjoyment, and thus putting off important tasks to a later time or not making a decision at all. According to Mann et al. (1997), vigilance is considered an adaptive way of decision making, while hypervigilance, buck-passing and procrastination are usually considered maladaptive. Concerning psychometric properties, Mann et al. (ibid.) confirmed satisfactory reliability of each factor using Cronbach alpha (from 0.74 for procrastination to 0.87 for hypervigilance and buck-passing). The current sample showed Cronbach alpha of 0.76 for vigilance, 0.69 for hypervigilance, 0.75 for buckpassing, and 0.82 for procrastination.

Situational characteristics of a decision making situation were measured by single items with 6-points Likert type response scale (from strongly disagree to strongly agree). For routine situations, the item was "The situation, in which decision had to be made, was common and routine". For situations with possible negative outcomes, the item was "In this situation, wrong decision could bring serious negative outcomes". Higher score indicates the manager's higher agreement with the description of the situation he or she chose.

\section{Results}

In the first step, correlation analysis was used to analyze relationships between decision making, self-regulation and situational aspects of a decision making situation. As there is some empirical evidence for the increase of self-regulation with age (e.g., Bauer et al., 2003), age and length of time at a job could have a possible impact on the results. Therefore, these variables were used as control variables for correlation analysis. This was also supported by slight but significant correlation between age and selfregulation $(r=0.21)$ and between age and procrastination $(r=-0.20)$. No correlations were found between age or length of time at a job and decision making variables.

The results of the analysis, together with descriptive characteristics, are presented in Table 1 , which shows self-regulation having a weak positive correlation with vigilance (representing adaptive behavior in a decision situation) and negative correlations with all three other decision making behaviors: hypervigilance, buck-passing and procrastination, which represent non-adaptive behavior during the decision situation. Self-regulation also has a positive but weak correlation with possible negative outcomes of a wrong decision in the situation, but not with a routine situation. Moreover, there are high positive correlations between all three negative decision making behaviors (hypervigilance, buck-passing and procrastination).

In the second step, moderation analysis was carried out, focusing on the moderation role of situations of routine and negative consequences in the relationship between self-regulation and decision making. To reduce the number of models tested for moderation, three MDMQ subscales variables representing maladaptive decision making styles were integrated into one variable. This was based on the high 
Table 1 List of study variables with their possible score ranges, mean scores, standard deviations, and Pearson's correlation matrix of the variables controlled for age and length of time at a job

\begin{tabular}{lrlllllll}
\hline Variable & Mean & SD & SRS & VGL & HVG & BCP & PRO & NEG \\
\hline SRS (10-40) & 31.02 & 4.62 & & & & & \\
VGL (0-12) & 10.30 & 2.15 & $\mathbf{0 . 2 3 * *}$ & & & & \\
HVG (0-10) & 3.01 & 2.09 & $\mathbf{- 0 . 4 0 * *}$ & -0.08 & & & \\
BCP (0-12) & 3.1 & 2.34 & $\mathbf{- 0 . 3 6 * *}$ & -0.16 & $\mathbf{0 . 5 7 * *}$ & & & \\
PRO (0-10) & 1.79 & 2.15 & $\mathbf{- 0 . 4 6 * *}$ & $\mathbf{- 0 . 3 5 * *}$ & $\mathbf{0 . 6 3 * *}$ & $\mathbf{0 . 6 4 * *}$ & & \\
NEG (0-6) & 4.45 & 1.56 & 0.08 & $\mathbf{0 . 2 5 * *}$ & 0.08 & -0.06 & -0.14 & \\
ROU (0-6) & 3.63 & 1.92 & 0.04 & -0.06 & -0.10 & -0.06 & -0.07 & 0.05 \\
\hline
\end{tabular}

Note. SRS - Self-Regulation Scale, VGL - Vigilance, HVG - Hypervigilance, BCP- Buck-passing, PRO - Procrastination, NEG - Situation with possible negative outcomes, ROU - Routine, common situation

$* p \leq .05, * * p \leq .01$

relations between these subscales, as identified in previous analysis. Factor analysis was chosen as the method for integration. Three maladaptive ways of decision making were factored by the maximum likelihood method and a person's regression score was saved as the new variable. This new variable was named maladaptive decision making. The moderation effect was estimated using the PROCESS macro developed by Hayes (2012). PROCESS is a computational macro for path analysis based moderation and it provides coefficient estimations using ordinary least squares (OLS) regression for continuous variables.

Together four analyses were carried out. In all models, self-regulation was set as the independent variable. Model 1 and Model 2 included vigilance as the dependent variable, however, Model 1 with routine situation characteristic as the moderator and Model 2 with negative consequences as the moderator. Both Models 3 and 4 included maladaptive decision making as the dependent variable, however, Model 3 had rou- tine situation as the moderator and Model 4 had negative consequences as the moderator.

The results of the analyses are presented in Table 2. As seen, the moderation effect of a routine situation was not identified as significant. These cases included Models 1 and 3. In both cases, interaction terms confidence intervals showed a non-significant effect of moderation and the increase of the percentage of variance explained by the model caused by interaction term was null. On the other hand, the moderation effect of a situation with possible serious negative outcomes was found to be significant in both vigilance and maladaptive decision making. In both cases, confidence intervals of interaction term do not reach zero value and increase of percentage explained by the model caused by interaction term is significant. In case of vigilance, the moderation effect is bigger (interaction term added $7.6 \%$ into variance explained) in comparison with maladaptive decision making (only $2.6 \%$ increase of variance explained due to moderation). 
Table 2 Results of moderation analysis with self-regulation as independent variable, vigilance and maladaptive decision making as dependent variables, and situation characteristics (routine or with possible negative outcomes) as moderators

\begin{tabular}{ccccc}
\hline Predictors & $\begin{array}{c}\text { Unstandardized } \\
\text { regression } \\
\text { coefficients }\end{array}$ & $\begin{array}{c}\text { 95\% Confidence } \\
\text { intervals }\end{array}$ & $\begin{array}{c}\text { R-square } \\
\text { whole model }\end{array}$ & $\begin{array}{c}\text { R-square increase } \\
\text { due to interaction }\end{array}$ \\
\hline Model 1 - vigilance as dependent variable & & \\
SRS & 0.123 & $(-0.034,0.281)$ & & \\
ROU & 0.015 & $(-1.192,1.222)$ & 0.251 & \\
SRS x ROU & -0.002 & $(-0.040,0.035)$ & & \\
Model 2 - vigilance as dependent variable & & \\
SRS & 0.414 & $(0.229,0.599)$ & \\
NEG & 2.709 & $(1.384,4.034)$ & 0.433 & \\
SRS x NEG & -0.076 & $(-0.118,-0.034)$ & & \\
Model 3 - maladaptive decision making as dependent variable & & \\
SRS & -0.110 & $(-0.170,-0.050)$ & & \\
ROU & -0.147 & $(-0.607,0.311)$ & 0.494 & \\
SRS x ROU & 0.004 & $(-0.010,0.018)$ & & \\
Model 4 - maladaptive decision making as dependent variable & & \\
SRS & -0.174 & $(-0.248,-0.099)$ & & \\
NEG & -0.614 & $(-1.148,-0.081)$ & 0.516 & \\
SRS x NEG & 0.019 & $(0.002,0.036)$ & & \\
\hline
\end{tabular}

Note. SRS - Self-Regulation Scale, NEG - Situation with possible negative outcomes, ROU

- Routine, common situation

$* p \leq .05, * * p \leq .01$

Figures 1 and 2 show graphical representation of the moderation effect as produced by PROCESS macro. Lines represent regression equations (self-regulation regressed on vigilance or maladaptive decision making) in three groups, according to the level of possible negative consequences in a situation of decision making. As seen in Figure 1, there is a strong positive relationship between self-regulation and vigilance in the group of low level of negative consequences of inappropriate decision making (dashed line). However, this relationship is lower when the level of negative outcomes increases (dotted line), and diminishes when negative consequences are high (solid line). This means that managers with low selfregulation do not apply vigilant decision mak- ing in situations without possible negative consequences, but they are able to use it when negative consequences of an inappropriate decision are possible. On the other hand, managers with high level of self-regulation use vigilant decision making in all situations. Figure 2 shows that the relationship between self-regulation and maladaptive decision making is negative in all groups, according to the extent to which serious negative consequences are possible after a wrong decision. However, the size of this relationship varies in the groups. The most intensive negative relationship is present in situations with low level of negative consequences (dashed line), and the least intensive in situations where possibility of negative consequences is the highest (solid line). 


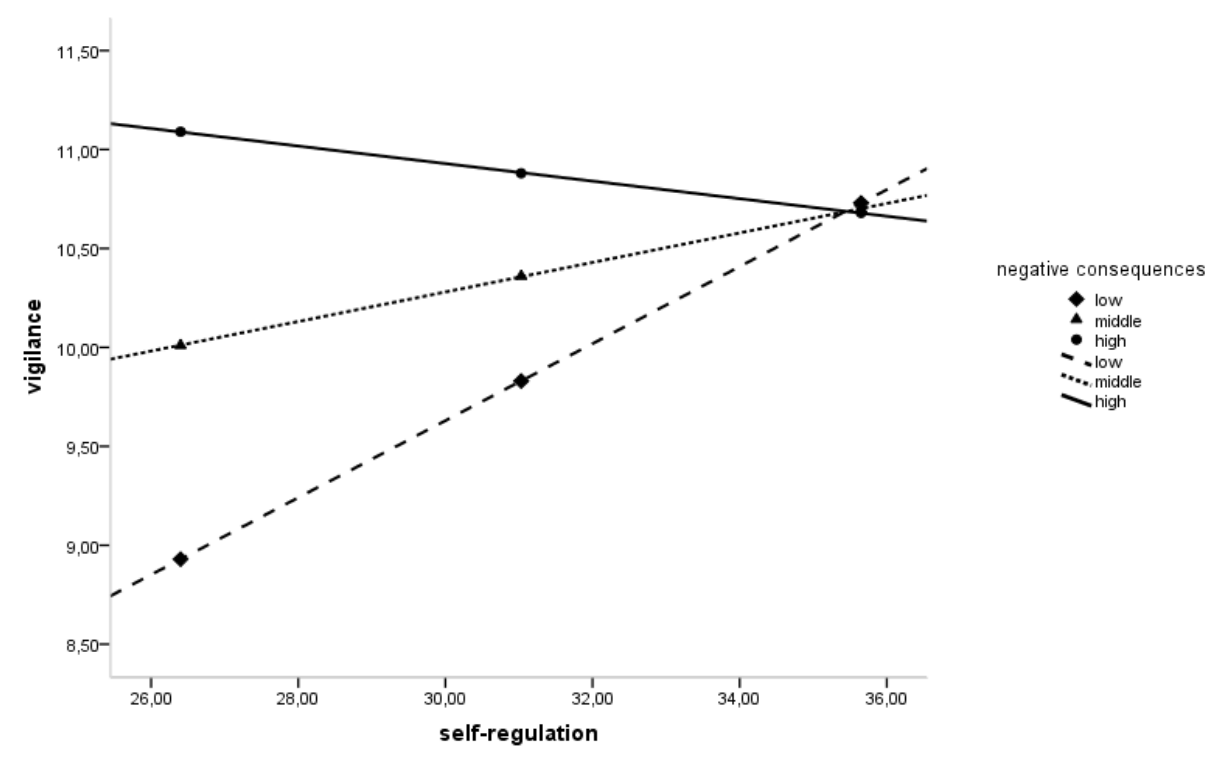

Figure 1 Graphical representation of moderation effect in model with self-regulation as independent variable, vigilance as dependent variable and possible negative consequences of decision as moderator

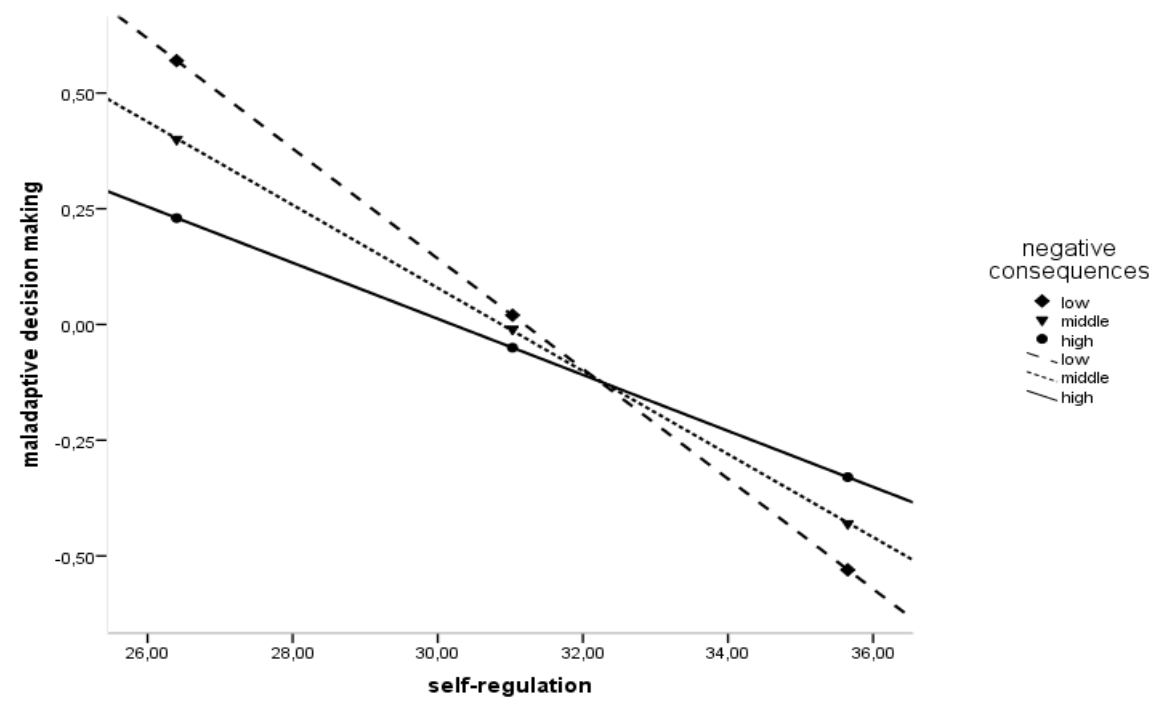

Figure 2 Graphical representation of moderation effect in model with self-regulation as independent variable, maladaptive decision making as dependent variable and possible negative consequences of decision as moderator 


\section{Discussion}

The current study aims to identify relationships between self-regulation capacity and the ways of decision making in specific work-related situations and investigate possible moderation effect of situation characteristics on these relationships. The results of the correlation analysis showed that the level of self-regulation in work situations of managers is positively related to the adaptive ways of decision making, which is represented by vigilance. Also, self-regulation has a negative relationship with maladaptive decision making represented by hypervigilance, buck-passing and procrastination. When using Cohen's (1992) criterion for effect sizes, correlation between self-regulation and vigilance is rather small, however, correlations between self-regulation and maladaptive ways of decision making in managerial situations reach a moderate level of effect size (around 0.4). This suggests that although selfregulation seems to be a partial factor in enhancing vigilant decision making, its role in prevention of maladaptive decision making is somewhat greater. Managers who have higher level of self-regulation are able to avoid maladaptive decision making strategies in their work situations more frequently than managers with low level of self-regulation. Previous theories related to self-regulation and decision making provide several links to how to understand this result. First of all, definition of self-regulation inevitably includes eliminating negative stimuli and controlling the prepotent response (Vohs et al., 2008; Halama, 2014) or to eliminate the hot system (Mischel, 1996; Metcalfe \& Mischel, 1999). Lack of self-regulation capacity causes inability to eliminate impulses, which divert a person's attention from regulatory focus and lead to preference of non-adaptive strategies. Strategies related to avoidance of decision making situation can also be evoked by presence of negative emotions. In this case, self-regulatory capacities have the potential to eliminate negative feelings coming from work-related threats such as time demands, sudden technical failures or interpersonal conflicts, and to help a person to focus on rational evaluation of a situation (Baumann et al., 2001). However, in case of low self-regulation capacity, overcoming negative emotions can lead not only to avoidance of decisions (buck-passing, procrastination), but also to impulsive search for a solution, which should bring relief from negative feelings (hypervigilance). Managers who prefer this option, can be involved in emotional and chaotic search for a quick solution to the problem and can overestimate emotionally irrelevant and underestimate emotionally relevant information.

Another important result of correlations analysis is related to the MDMQ measure itself. There are high correlations between all maladaptive decision making styles. These findings are common in different samples and settings (e.g., Di Fabio \& Palazzeschi, 2012; Halama \& Pitel, 2016) and in this study, they are grounds for composing one single variable under the name maladaptive decision making. However, the robustness of these findings, together with the lack of evidence that three maladaptive subscales differ consistently in their relationships with other variables, suggests a need to reconsider the original structure of MDMQ set by Mann et al. (1997) and find a proper way for dimensions of MDMQ to be useful in psychological research.

Moderation analysis showed that only situations with possible negative consequences had a significant moderation effect on the relationship between self-regulation and ways of decision making. No moderation effect was found in case of routine situations either for adaptive (vigilance) or maladaptive decision making. Although there was no measure of negative emotions in the decision making situation, we can hypothesize that this moderation effect can be 
caused by negative emotions possibly present is such situations. Managerial situations, in which a manager perceives serious negative consequences of his or her decision, can evoke negative emotions related to decision making result, such as anxiety, worries, etc., which can influence cognitive processes related to decision making. Although previous research on self-regulation and decision making suggests that negative emotion can be a threat to adaptive decision making, especially in people with low self-regulation capabilities (Baumann et al., 2001, Halama \& Gurňáková, 2013), these results point to the potential positive role of negative emotions. Managers with low self-regulation tend to use less vigilant decision making in comparison to managers with high self-regulatory capabilities, but only in situations where negative consequences are not probable or less probable (Figure 1). When possible negative consequences are present in a situation, vigilant decision making is applied regardless of the selfregulation level. Similar effect, although not so intensive, was found in maladaptive decision making as well. The tendency to use maladaptive decision making is higher for managers with low self-regulation, but this effect is smaller in situations with possible negative consequences (Figure 2). Both these findings suggest that presence of negative consequences can work as a protective factor leading to more adaptive decision making. The possible explanation of these findings can be based on the motivational function of all emotions, including negative ones (Zeelenberg et al., 2008). Negative affective responses in situations with possible negative consequences can serve as a source of information and feedback (Carver et al., 2014) and they can help to focus attention on a problem. For managers with low self-regulation, utilizing vigilant decision making only in situations with perceived negative consequences, can be an adaptive way to save their cognitive resources, because decision making can be energy con- suming (Vohs et al., 2008). However, there is a question about the level of negative consequences, which makes negative emotions able to help in adaptive decision making, because negative emotions sometimes lead to self-regulation failure (Heatherton \& Wagner, 2011). Further research should focus on the conditions in which negative emotions affect decision making positively or negatively. The findings from this study have several possible implications, especially in the area of work and organizational psychology. First of all, the fact that managers with higher self-regulation capacities tend to use a vigilant approach to decision making and, therefore, perform better in managerial jobs, can be an important source of information during personnel selection. As suggested by moderation analysis, high self-regulation capacity can be an important factor of job performance, especially in positions where direct external demands for achievements are weak and limited and a manager has to rely on personal resources. Also, developmental programs and trainings related to the so called "soft skills" should include components related to strengthening and developing better self-regulation capacities.

One limitation of the study comes from the self-report character of the data. No other kind of data (observation, peer assessment) were included in the study, so there is a certain possibility that the data could be biased by selfevaluation of the managers. Another important limitation is that characteristics of the situation were measured only by one single item. Although this is not unusual in the area of situation measures (see Rauthmann \& Sherman, 2016, for example), single item can significantly reduce variance of the measured phenomena and bias the results of statistical analysis. Moreover, single item is limited in detailed description of the situation, e.g. there was no detailed identification of negative consequences. One of the limitations comes from the fact, that man- 
agers reported different situations of decision making and this variability can influence the results. The situations might substantially differ in multiple aspects, such as complexity and proper solving strategies, and this variability can make comparisons between managers more difficult. In addition, the choice of the situation can be influenced by some individual dispositions, which were not controlled in the study. Finally, the methodological design of this study is correlational without any longitudinal or experimental components. Therefore, causal interpretation of these results is limited and should be made only with reference to other supportive findings.

\section{Conclusion}

Results confirmed that self-regulation plays an important role in the process of decision making carried out in work-related situations. Based on the results of correlation analysis, high self-regulation was shown to be a positive factor in decision making through increasing vigilant thinking and eliminating maladaptive ways, such as procrastination or buck-passing. Results also confirmed the assumption about situational effect, especially when a situation involves possible negative consequences of an inappropriate decision. It seems that such a situation increases the level of vigilant approach and decreases the level of maladaptive approach to decision making among managers with low level of self-regulation. Further research should focus on the problem of how perception of negative consequences interacts with significant personality variables in predicting the decision making process in managerial settings.

\section{References}

Arrow, K. (1958). Utilities, attitudes, choices: A review note. Econometrica, 26(1), 1-23.
Bauer, M. J., Adler, G., Kuskowski, M. A., \& Rottunda, S. (2003). The influence of age and gender on the driving patterns of older adults. Journal of Women \& Aging, 15(4), 3-16.

Baumann, M. R., Sniezek, J. A., \& Buerkle, C. A. (2001). Self-evaluation, stress and performance: A model of decision making under acute stress. In E. Salas \& G. Klein (Eds.), Linking expertise and naturalistic decision making (pp. 139-158). New York, London: Psychology Press.

Baumeister, R. F. (2002). Yielding to temptation: Selfcontrol failure, impulsive purchasing, and consumer behavior. Journal of Consumer Research, 28, 670676.

Baumeister, R. F., Bratslavsky, E., Muraven, M., \& Tice, D. M. (1998). Ego depletion: Is the active self a limited resource? Journal of Personality and Social Psychology, 74, 1252-1265.

Betsch, T., Haberstroh, S., \& Hohle, C. (2002). Explaining routinized decision making a review of theories and models. Theory \& Psychology, 12(4), 453-488.

Byrnes, J. P. (1998). The nature and development of decision-making: A self-regulation model. New York: Psychology Press.

Byrnes, J. P. (2005). The development of self-regulated decision making. In J. E. Jacobs \& P. A. Klaczynski (Eds.), The development of judgment and decision making in children and adolescents (pp. 5-38). Mahwah, NJ: Lawrence Erlbaum Associates.

Carver, C. S., Lawrence, J. W., \& Scheier, M. F. (2014). A control-process perspective on the origins of affect. In L. L. Martin \& A. Tesser (Eds.) Striving and feeling: Interactions among goals, affect, and selfregulation (pp. 11-52) New York, London: Psychology Press.

Carver, C. S., \& Scheier, M. F. (1981). Attention and self-regulation: A control-theory approach to human behaviors. New York: Springer-Verlag.

Carver, C. S, \& Scheier, M. F. (1998). On the selfregulation of behaviour. New York: Cambridge University Press.

Carver, C. S., \& Scheier, M. F. (2004). Self-regulation of action and affect. In K. D. Vohs \& R. F. Baumeister (Eds.) Handbook of self-regulation: Research, theory, and applications (pp. 13-39). New York: Guilford Press.

Cohen, J. (1992). A power primer. Psychological Bulletin, 112(1), 155-159.

Crowe, E., \& Higgins, E. T. (1997). Regulatory focus and strategic inclinations: Promotion and prevention in decision making. Organizational Behavior and Human Decision Processes, 69, 117-132.

Derakshan, N., \& Eysenck, M. W. (2009). Anxiety, processing efficiency and cognitive performance. 
New developments from attentional control theory. European Psychologist, 14, 2, 168-176.

Diehl, M., Semegon, A. B., \& Schwarzer, R. (2006). Assessing attention control in goal pursuit: A component of dispositional self-regulation. Journal of Personality Assessment, 86, 306-317.

Di Fabio, A., \& Palazzeschi, L. (2012). Incremental variance of the core self-evaluation construct compared to fluid intelligence and personality traits in aspects of decision-making. Personality and Individual Differences, 53(3), 196-201.

Edwards, W. (1954). The theory of decision making. Psychological Bulletin, 51(4), 380-417.

Endler, N. S., \& Edwards, J. M. (1986). Interactionism in personality in the twentieth century. Personality and Individual Differences, 7(3), 379-384.

Eysenck, M. W., Derakshan, N., Santos, R., \& Calvo, M. G. (2007). Anxiety and cognitive performance: Attentional Control Theory. Emotions, 7(2), 336353.

Frederick, S. (2005). Cognitive reflection and decision making. The Journal of Economic Perspectives, 19(4), 25-42.

Golwitzer, P. M., \& Sheeran, P. (2009). Self-regulation of consumer decision making and behavior: The role of implementation intentions. Journal of Consumer Psychology, 19, 593-507.

Halama, P. (2013). Pät' vel'kých faktorov osobnosti ako prediktory vnímanej efektivity rozhodovania zdravotníckych profesionálov. In J. Gurňáková a kol., Rozhodovanie profesionálov: Sebaregulácia, stres a osobnost' (pp. 161-184). Bratislava: Ústav experimentálnej psychológie SAV.

Halama, P. (2014) Sebaregulácia ako faktor v procese rozhodovania. In E. Ballová Mikušková \& V Čavojová (Eds.) Rozhodovanie v kontexte kognície, osobnosti a emócii IV: Súčasné trendy v rozhodovani (pp. 89-96). Bratislava: Ústav experimentálnej psychológie SAV.

Halama, P. (2016). Interakčný prístup k skúmaniu rozhodovania $v$ pracovnej oblasti. In I. Sarmány Schuler (Ed.), Rozhodovanie v kontexte kognicie, osobnosti a emócií $V$. Nitra: Univerzita Konštantína Filozofa.

Halama, P., \& Gurňáková, J. (2012). Emócie a emočná regulácia $\mathrm{v}$ procese rozhodovania u zdravotníckych záchranárov. In P. Halama, R. Hanák, \& R. Masaryk, (Eds.), Sociálne procesy a osobnost' 2012. Zbornik príspevkov z 15. ročníka medzinárodnej konferencie. (pp. 215-218). Bratislava: Ústav experimentálnej psychológie SAV.

Halama, P., \& Pitel, L. (2016). Relationship between adult attachment and decision making in hospital nurses is mediated by self-regulation ability. Studia Psychologica, 58(2), 122-133.
Hayes, A. F. (2012). PROCESS: A versatile computational tool for observed variable mediation, moderation, and conditional process modeling [White paper]. Retrieved from http://www.afhayes.com/ public/process2012.pdf

Heatherton, T. F., \& Wagner, D. D. (2011). Cognitive neuroscience of self-regulation failure. Trends in Cognitive Sciences, 15(3), 132-139.

Higgins, E. T. (2002). How self-regulation creates distinct values: The case of promotion and prevention decision making. Journal of Consumer Psychology, 12, 177-191.

Hochwarter, W. A., Witt, L. A., Treadway, D. C., \& Ferris, G. R. (2006). The interaction of social skill and organizational support on job performance. Journal of Applied Psychology, 91(2), 482-489.

Jurišová, E., \& Sarmány-Schuller, I. (2013). Structure of basal psychical self-regulation and personality integration in relation to coping strategies in decisionmaking in paramedics. Studia Psychologica, 55(1), 3-17.

Kahneman, D., \& Tversky, A. (1984). Choices, values, and frames. American Psychologist, 39(4), 341350 .

Mann, L., Burnett, P., Radford, M., \& Ford, S. (1997). The Melbourne Decision Making Questionnaire: An instrument for measuring patterns for coping with decisional conflict. Journal of Decision Making, 10, 1-19.

Metcalfe, J., \& Mischel, W. (1999). A hot/cool-system analysis of delay of gratification: Dynamics of willpower. Psychological Review, 106(1), 3-19.

Mischel, W. (1996). From good intentions to willpower. In P. M. Gollwitzer \& J. A. Bargh (Eds.), The psychology of action: Linking cognition and motivation to behavior (pp. 197-218). New York: Guilford Press.

Miu, A. C., Heilman, R. M., \& Houser, D. (2008). Anxiety impairs decision-making: Psychophysiological evidence from an Iowa Gambling Task. Biological Psychology, 77(3), 353-358.

Mosier, K. L., \& Fischer, U. (2010). The role of affect in naturalistic decision making. Journal of Cognitive Engineering and Decision Making, 4, 240-255.

Rauthmann, J. F., \& Sherman, R. A. (2016). Ultrabrief measures for the situational eight DIAMONDS domains. European Journal of Psychological Assessment, 32, 165-174.

Richters, F., Schraagen, J. M., \& Heerkens, H. (2016). Assessing the structure of non-routine decision processes in airline operations control. Ergonomics, 59(3), 380-392.

Sedlár, M. (2016). Rozhodovanie zdravotníckych profesionálov $\mathrm{v}$ rutinných a nerutinných situáciách. [Dizertačná práca]. Bratislava: Fakulta sociálnych a 
ekonomických vied, Univerzita Komenského v Bratislave.

Schwarzer, R., Diehl, M., \& Schmitz, G. S. (1999). Self-Regulation Scale. Retrieved October 28, 2014 , from http://userpage.fu-berlin.de/ health/selfreg_e. htm.

Tett, R. P., \& Burnett, D. D. (2003). A personality trait-based interactionist model of job performance. Journal of Applied Psychology, 88(3), 500-517.
Vohs, K. D., Baumeister, R. F., Schmeichel, B. J., Twenge, J. M., Nelson, N. M., \& Tice, D. M. (2008). Making choices impairs subsequent self-control: A limited-resource account of decision making, selfregulation and active initiative. Journal of Personality and Social Psychology, 94(5), 883-898.

Zeelenberg, M., Nelissen, R. M., Breugelmans, S. M., \& Pieters, R. (2008). On emotion specificity in decision making: Why feeling is for doing. Judgment and Decision Making, 3(1), 18-27. 